\title{
Cost reduction of the new NZEB Wooden building - case study of the kindergarten in Estonia.
}

\author{
Endrik Arumägi ${ }^{1, *}$, Targo Kalamees ${ }^{1}$ \\ ${ }^{1}$ Tallinn University of Technology, Nearly Zero Energy Buildings Research Group, Ehitajate tee 5, 19086 Tallinn, Estonia
}

\begin{abstract}
In this study the cost changes caused by the implementation of the nZEB solutions are calculated. The energy demand of a building was calculated according to the methodology for calculating the energy efficiency of buildings, using dynamic energy simulations. The financial calculations are based on the methodology described in Delegated Regulation (EU) No 244/2012 of the European Commission. The simulations and calculations for assessing the cost-effectiveness of technical solutions are based on the selected sample building. The energy efficiency solutions are derived by increasing/decreasing the insulation value of the building envelope in subsequent steps. Financial calculations were based on the investment needed to achieve the nearly zero-energy levels. The results for different combinations vary to a large degree. According to regulations new building must fulfill the low energy building (EPI class "B") requirement without local production. The EPI value to fulfill the requirement in the cost-even range is reached in case of the GSHP and efficient DH. In case of the GSHP and efficient DH also the cost-optimal point is in the EPI class "B". Overall the minimum $\triangle \mathrm{NPV}$ values stay below the zero line in all the cases offering a range of opportunities to choose combinations to reach lover EPI compared to base case. The results of costeffectiveness calculations for selected building with different combinations of structural solutions and heat sources show the possible different scenarios to reach nZEB level and the possible cost reduction.
\end{abstract}

\section{Introduction}

In the European Union, Energy Performance of Buildings Directive 2010/31/EU (EPBD) [1] obligates Member States (MS) to assure that minimum energy performance requirements for buildings are set to achieve cost-optimal levels. As of 2020, the minimum requirement for all new and significantly renovated buildings in the EU is the nZEB level [2]. The directive [1] describes nZEB as a building with very high energy performance. The low amount of energy required to 'run' the building should be covered mostly by energy from on-site renewable sources such as photovoltaic solar panels (PV-panels).

The cost-optimal level is defined as "the energy performance level which leads to the lowest cost during the estimated economic lifecycle" [1] from two different perspectives: financial (looking at the investment itself at the building level) and macro-economic (looking at the costs and benefits of energy efficiency for society as a whole). The analysis needs to include best available technical solutions and therefore enable the assessment of nZEB performance levels and cost implications with very little extra effort [3].

Current practice [3-5] has shown that more thorough sensitivity analyses are needed in the design to find suitable solutions, possible compromises between architecture and energy efficiency and to avoid large differences in calculated and measured energy performance values. Sankelo et al. [4] showed that extensive insulation of the building envelope is not a cost- optimal method to reduce the daycare building energy use but improving energy efficiency of the ventilation system, utilising solar energy on-site and employing a light control strategy are preferable ways of improving the building energy performance. Alanne et al. [6] investigated different thermal insulation and air tightness properties of the building envelope, and different ventilation's heat recovery efficiency assumptions and heat distribution options in educational buildings in Finland and showed that total energy-saving potential of $25-32 \%$ can be obtained. Saari et al. [7] analyzed alternative energy-saving design concepts for a typical new detached house design in Finland and showed that the payback period was shortest for the air source heat pumps.

Marszal [8] analyzed renewable energy supply systems and user profiles of a multi-story residential net ZEB and showed that with current energy prices and technology, a cost-optimal zero energy balance accounts for only the building related energy use.

. In this case a day care center has been selected as an example building. The cost changes caused by the implementation of different insulation measures to reach the nZEB level are calculated. Study focuses on questions concerning more cost-efficient solutions to reach the nZEB level especially in wooden buildings.

* Corresponding author: endrik.arumagi@,ttu.ee 


\section{Methods}

The analysis includes detailed energy performance related costs of the actual solution components compared with the reference solution (minimum requirements, building as usual (BAU) solutions). Cost due to operational energy use and renewable energy harvesting are calculated. Additionally, to LCC calculations also LCA calculations are performed. The goal of the LCA study is to analyse and document the GHG emissions from the production phase and operational energy use of the nZEB building.

The energy efficiency solutions are derived by increasing/decreasing the insulation value of the building envelope (external walls, roof, and ground floor) in subsequent steps. These follow the actual building energy efficiency solution (as in the planning phase) and a proposal for an energy efficiency improvement to be implemented in the future building is presented.

\subsection{Building description}

Studied building has 1 floor and row floor plan (see Fig. 1). External walls are wooden frame construction with thermal insulation of mineral wool insulation. Roof has insulation of loose fibre insulation. Ground floor is $100 \mathrm{~mm}$ concrete with insulation of EPS insulation. Windows are wooden frame windows with triple glazing. Heating system has a ground source heat pump (GSHP) $(\mathrm{Q}=45 \mathrm{~kW} \mathrm{COP}=4.8)$ or district heating $(\mathrm{DH})$ for space heating, ventilation supply air heating and domestic hot water. Floor heating is used on the first floor. Temperature is regulated on heat substation according to the outdoor temperature and with room thermostats. Ventilation system has four supply-exhaust air handling units with heat recovery. Supply air is directed to the children's sleeping and playrooms. Exhaust air is removed from toilets, bathrooms and dressing rooms. Design supply air temperature is $21^{\circ} \mathrm{C}$.
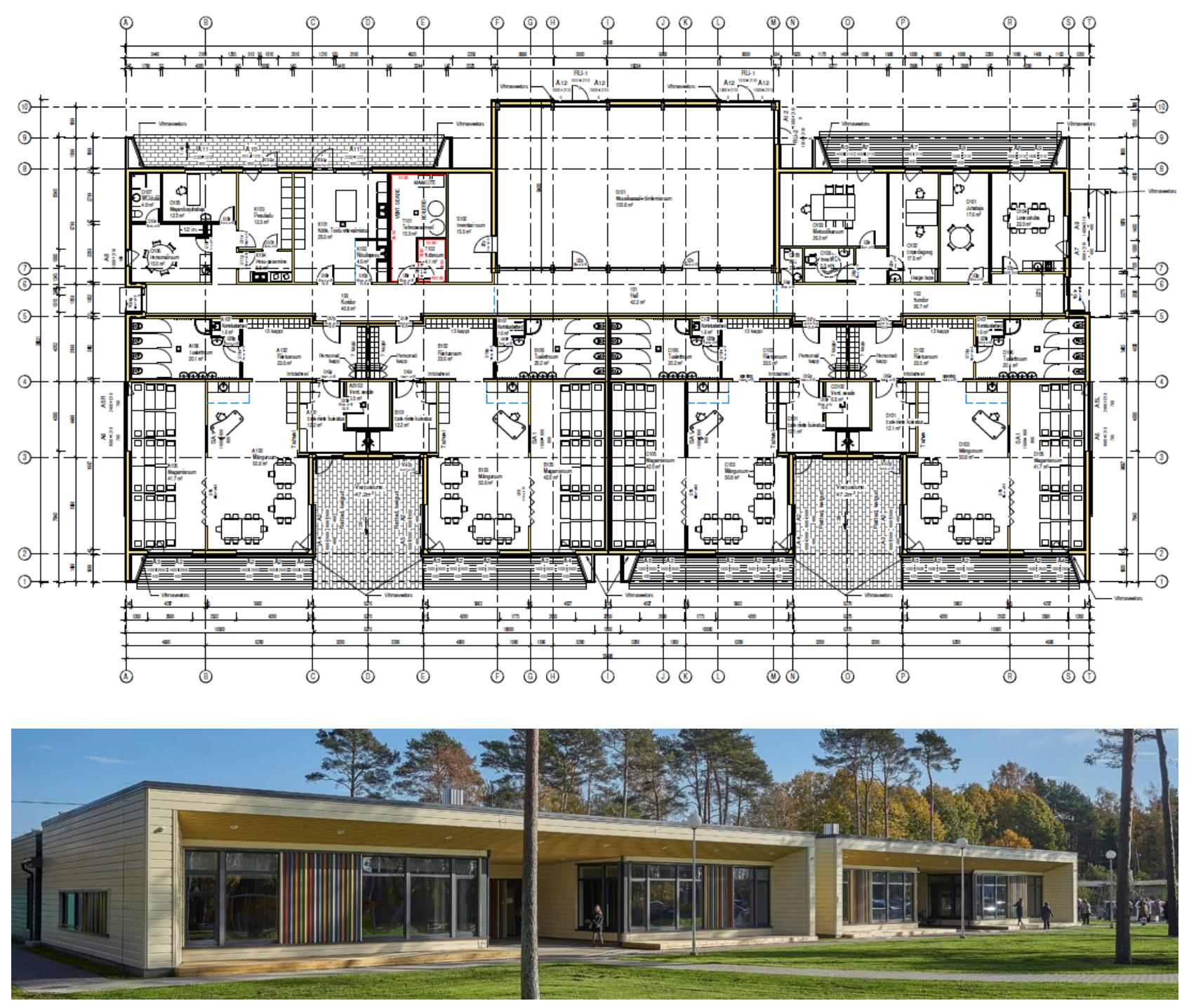

Fig. 1 Floor plan and the view of the studied building. 
Table 1. Basic information of the building.

\begin{tabular}{|c|c|c|}
\hline \multicolumn{3}{|l|}{ Building data } \\
\hline Building type & \multicolumn{2}{|c|}{ Day care centre } \\
\hline Net floor area & 1111.7 & $\mathrm{~m}^{2}$ \\
\hline Heated area & 1111.7 & $\mathrm{~m}^{2}$ \\
\hline \multicolumn{3}{|l|}{ Climate data } \\
\hline $\begin{array}{l}\text { Design outdoor temperature for } \\
\text { heating }\end{array}$ & -22 & ${ }^{\circ} \mathrm{C}$ \\
\hline $\begin{array}{l}\text { Design outdoor temperature for } \\
\text { cooling }\end{array}$ & 27 & ${ }^{\circ} \mathrm{C}$ \\
\hline Heating degree days, $\mathrm{t}_{\mathrm{b}}-17^{\circ} \mathrm{C}$ & 4220 & ${ }^{\circ} \mathrm{C}$ \\
\hline Cooling degree days & none & ${ }^{\circ} \mathrm{C}$ \\
\hline \multicolumn{3}{|c|}{ Building insulation (initial estimation) } \\
\hline $\begin{array}{l}\text { Exterior wall thermal } \\
\text { transmittance }\end{array}$ & 0.18 & $\mathrm{~W} /\left(\mathrm{m}^{2} \mathrm{~K}\right)$ \\
\hline Roof thermal transmittance & 0.09 & $\mathrm{~W} /\left(\mathrm{m}^{2} \mathrm{~K}\right)$ \\
\hline Base floor thermal transmittance & 0.19 & $\mathrm{~W} /\left(\mathrm{m}^{2} \mathrm{~K}\right)$ \\
\hline Window thermal transmittance & 0.9 & $\mathrm{~W} /\left(\mathrm{m}^{2} \mathrm{~K}\right)$ \\
\hline Window g-value & $0.27-0.40$ & \\
\hline \multicolumn{3}{|c|}{ Basic system information (initial estimation) } \\
\hline Ventilation system & \multicolumn{2}{|c|}{$\begin{array}{l}\text { Mechanical supply and } \\
\text { exhaust with heat } \\
\text { recovery }\end{array}$} \\
\hline Heating system & \multicolumn{2}{|c|}{ Hydronic floor heating } \\
\hline Heating source & \multicolumn{2}{|c|}{$\begin{array}{l}\text { Ground source heat } \\
\text { pump / district heating }\end{array}$} \\
\hline Cooling system & \multicolumn{2}{|l|}{ No } \\
\hline Cooling source & \multicolumn{2}{|l|}{ No } \\
\hline $\begin{array}{l}\text { Onsite production/Renewable } \\
\text { sources }\end{array}$ & \multicolumn{2}{|l|}{ PV panels } \\
\hline \multicolumn{3}{|l|}{ Internal heat gains } \\
\hline Operation hours & $\begin{array}{l}7: 00- \\
19: 00\end{array}$ & hour \\
\hline days/week & 5 & day \\
\hline hours/day & 12 & hour \\
\hline hours/year & 3120 & hour \\
\hline Mean occupant density & 10 & $\mathrm{~m}^{2} /$ person \\
\hline
\end{tabular}

\subsection{Energy calculations}

The energy performance of buildings in Estonia is expressed as an annual primary energy (PE) usage and presented as the energy performance indicator (EPI, $\left.\mathrm{kWh} /\left(\mathrm{m}^{2} \cdot \mathrm{a}\right)\right)$. The EPI includes the heat and fuel consumption for space heating, heating of ventilation and infiltration air, domestic hot water and cooling as well, electricity for lighting, electrical appliances, and technical systems. To calculate the EPI from delivered energy, the conversion factors for energy carriers are:

- electricity 2.0;

- district heating 0.9 ;

- efficient district heating 0.65 .
The energy demand of a building was calculated according to the national methodology for calculating the energy efficiency of buildings [9], using dynamic energy simulation software IDA Indoor Climate and Energy 4.7.1 (IDA-ICE) [10]. The software used for calculations meets all the software requirements in the regulation on minimum energy performance requirements. The results obtained from the dynamic simulations were used to assess the energy savings potential of different energy efficiency measures and to calculate the energy use of buildings with different structural solutions.

A room-based simulation model was developed for the building. The models were designed according to the architectural bases, views and sections of buildings. The solutions for openings and the building envelope were selected according to the building design.

First, simulation models were developed to assess the impact of individual components of the building envelope on the energy use of the building. In the initial energy simulations, only one component was changed, and the result was compared to the energy use of the original building. The variable of the individual modifiable components was the thermal transmittance of the relevant component. In addition to the thermal transmittance, the effect of the building's air permeability was also assessed.

The values of thermal transmittance $\left(U . \mathrm{W} /\left(\mathrm{m}^{2} \cdot \mathrm{K}\right)\right)$ and air leakage $\left(q_{50}, \mathrm{~m}^{3} /\left(\mathrm{h} \cdot \mathrm{m}^{2}\right)\right)$ of different structural solutions used in simulation models were as follows:

- external wall $\left[\mathrm{W} /\left(\mathrm{m}^{2} \cdot \mathrm{K}\right)\right]$ : 0.183, 0.171, 0.153, 0.123;

- roofing deck $\left[\mathrm{W} /\left(\mathrm{m}^{2} \cdot \mathrm{K}\right)\right]: 0.070,0.093,0.069,0.064$

- floor $\left[\mathrm{W} /\left(\mathrm{m}^{2} \cdot \mathrm{K}\right)\right]: 0.15,0.122,0.111,0.084,0.068$;

- windows $\left[\mathrm{W} /\left(\mathrm{m}^{2} \cdot \mathrm{K}\right)\right]: 1.0,0.7$ with varying $\mathrm{g}$-values;

- $\mathrm{q}_{50}$ value $\left[\mathrm{m}^{3} /\left(\mathrm{h} \cdot \mathrm{m}^{2}\right)\right]: 1.0$ and 0.6 .

In addition to assessing the impact of the individual components on the building's energy use, the calculation of the energy efficiency indicator was performed for all combinations by combining various

values of thermal conductivity and air leakage of structural solutions

\subsection{Cost-effectiveness calculations}

The unit prices required for calculating the additional cost of various structural solutions affecting the energy use of buildings were obtained from construction companies by the building type. The budget officers provided unit costs per square meter for various structural solutions and openings, which also included the costs of material and installation. The costs of solar panels were estimated. The costs of structures, openings and technical systems were calculated by the companies. All calculated costs included VAT.

The financial calculations are based on the methodology described in Delegated Regulation (EU) No 244/2012 of the European Commission.

The cost-effectiveness of different structural solutions was estimated using the net present value (NPV) method:

$$
\left.C_{G(\tau)}=C_{i}+\sum_{i=1}^{\tau}\left(C_{a, i}\right) \cdot R_{d}(i)\right)
$$

where: 
- $\tau$ means the calculation period;

- $\mathrm{C}_{\mathrm{G}(\tau)}$ means total cost (referred to starting year $\tau 0$ ) over the calculation period;

- $\mathrm{C}_{\mathrm{i}}$ means initial investment costs for measure or set of measures j;

- $\mathrm{C}_{\mathrm{a}, \mathrm{i}(\mathrm{j})}$ means annual cost during year i for measure or set of measures j;

- $\mathrm{R}_{\mathrm{d}(\mathrm{i})}$ means discount factor for year $\mathrm{i}$.

The cost effectiveness of the additional costs related to structural solutions and renewable energy solutions that were needed to meet the requirements of the nearly zeroenergy building was assessed in these calculations:

$$
\triangle N P V=\left(C_{G}^{n Z E B}-C_{G}^{r e f}\right) / A_{\text {floor }}
$$

The discount was calculated using the calculated interest rate and a relative price increase during the calculation period. Depending on the uses of the buildings, the cost-effectiveness calculation period was chosen to be 20 years (for non-residential buildings). The discount was based on the real interest rate of $4.0 \%$, which corresponds to the rate of return of $5 \%$ when inflation is $1 \%$. The real escalation of energy prices for the calculation period was taken at $2 \%$ per annum.

The initial purchase price of energy carriers was calculated at the following prices (including VAT):

- electricity purchase $0.13428 \mathrm{EUR} / \mathrm{kWh}$;

- district heating $0.060 \mathrm{EUR} / \mathrm{kWh}$.

Financial calculations were based on the investment needed to achieve the nearly zero-energy levels. When calculating the additional cost of the measure/package, the prices payable by the customer, including all applicable taxes, VAT and support were taken into account in the financial calculations. The calculations did not take into account the potential support that may apply to the introduction of various technologies related to the production of renewable energy.

The cost of building components was calculated by totaling the different expense types and by applying a discount rate to them using the discount factor.

The criterion of profitability is that the net revenue generated and discounted during the economic life of the investment should be greater than the initial investment.

Table 2. Parameter values used for discount.

\begin{tabular}{|c|c|}
\hline Name & Value (VAT 0\%) \\
\hline $\begin{array}{c}\text { Thermal energy price, (district } \\
\text { heating) EUR/kWh }\end{array}$ & 0.050 \\
\hline $\begin{array}{c}\text { Electricity price, EUR/kWh } \\
\text { grid EUR/kWh }\end{array}$ & 0.1119 \\
\hline $\begin{array}{c}\text { Electricity price, when sold to the } \\
\text { Real interest rate, } \%\end{array}$ & 0.035 \\
\hline Escalation (electricity), \% & 4.0 \\
\hline Escalation (thermal energy), \% & 2 \\
\hline
\end{tabular}

\begin{tabular}{|c|c|}
\hline $\begin{array}{c}\text { Calculation period for residential } \\
\text { buildings, years }\end{array}$ & 30 \\
\hline
\end{tabular}

\subsection{Building envelope solutions cost}

The costs of the structural solutions for building based on the bids were received from contractor. Example of the price deviation are presented in the following graphs (from Fig. 2 to Fig. 5). The estimated cost of the structures is presented depending on the thermal transmittance. In case of the studied building, only timber frame constructions were accounted excluding the floor.

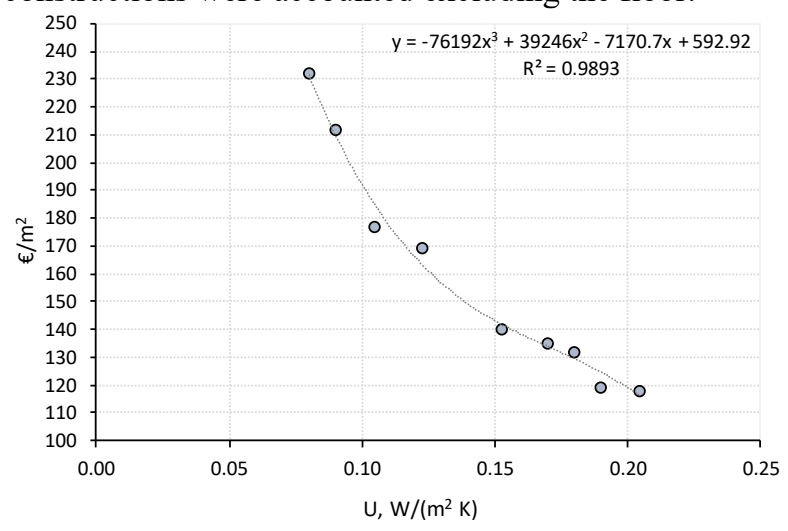

Fig. 2 Cost of timber frame walls.

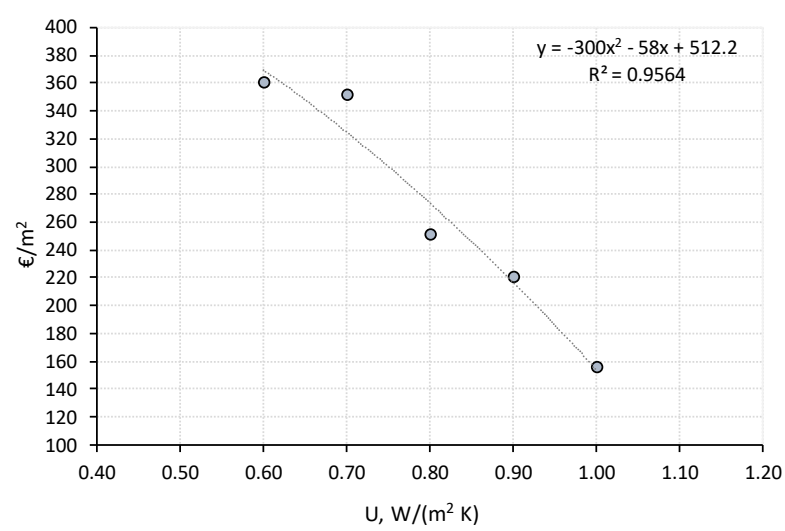

Fig. 3 Cost of windows

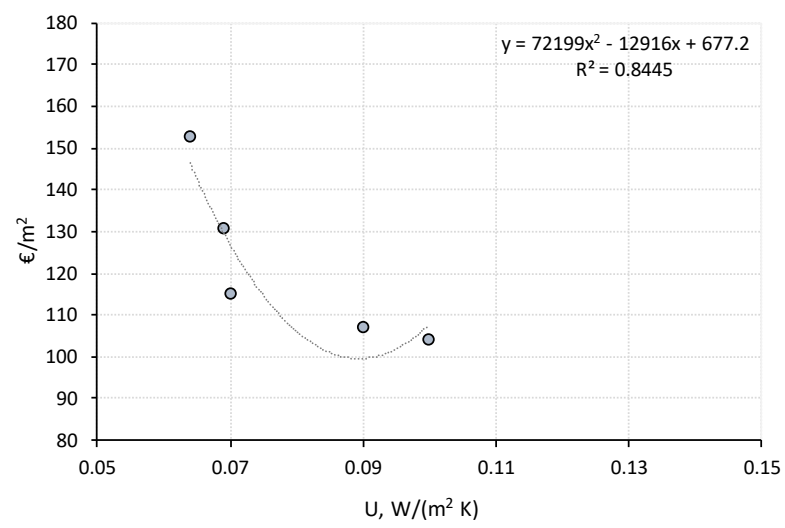

Fig. 4 Cost of timber frame roofs. 


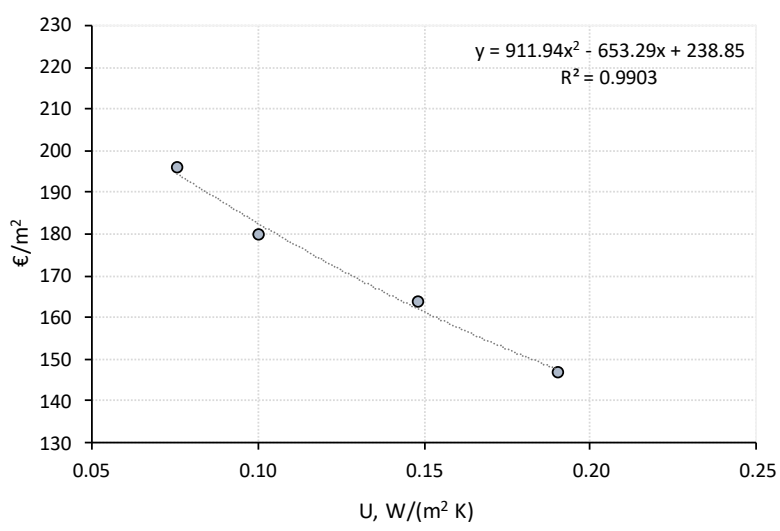

Fig. 5 Cost of concrete floor.

\section{Results}

\subsection{Energy calculations}

Calculated annual delivered energy use is as follows:

- room heating $9.3 \mathrm{kWh} /\left(\mathrm{m}^{2} \cdot \mathrm{a}\right)$;

- ventilation air heating $16.8 \mathrm{kWh} /\left(\mathrm{m}^{2} \cdot \mathrm{a}\right)$;

- hot water

- appliances

- lighting $10.0 \mathrm{kWh} /\left(\mathrm{m}^{2} \cdot \mathrm{a}\right)$; $5.0 \mathrm{kWh} /\left(\mathrm{m}^{2} \cdot \mathrm{a}\right)$; $12.5 \mathrm{kWh} /\left(\mathrm{m}^{2} \cdot \mathrm{a}\right)$;

- fans and pumps $16.3 \mathrm{kWh} /\left(\mathrm{m}^{2} \cdot \mathrm{a}\right)$;

Sum of delivered energy is $70 \mathrm{kWh} /\left(\mathrm{m}^{2} \cdot \mathrm{a}\right)$.

Energy performance indicator (EPI) without local renewable energy production, based on energy calculations by designer is $140 \mathrm{kWh} /\left(\mathrm{m}^{2} \cdot \mathrm{a}\right)$ that corresponds to class "B". By adding local renewable energy production, PV-panels on roof, the class "A" or nZEB can be achieved.

\subsection{LCC calculations}

The simulations and calculations for assessing the costeffectiveness of technical solutions are based on the selected sample building.

Next figures (from Fig. 6 to Fig. 8) show the results of cost-effectiveness calculations for the studied building with different combinations of structural solutions and heat sources.

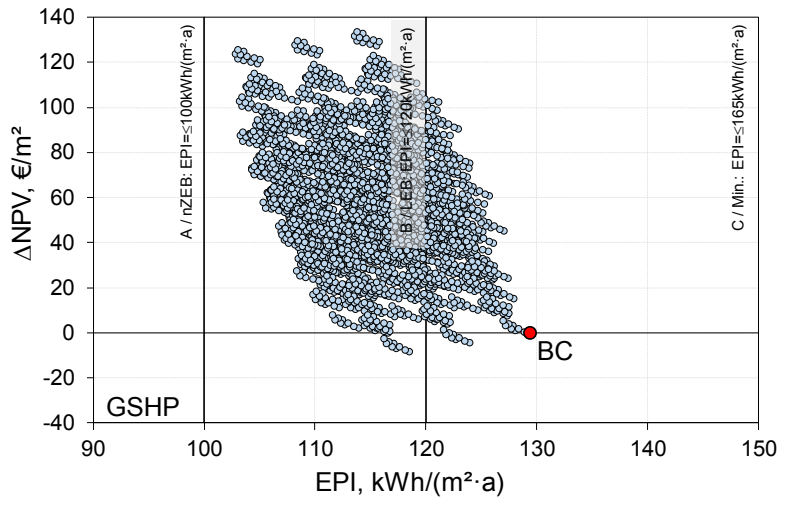

Fig. 6 Energy performance indicator (EPI) and change in the net present value $(\triangle \mathrm{NPV})$ for different combinations of structural solutions with the ground source heat pump (GSHP).
In the case of a GSHP (Fig. 6), the cost-even range of energy performance indicator (EPI) without local production of renewable energy compared to the base case (BC) is between 115 and $128 \mathrm{kWh} /\left(\mathrm{m}^{2} \mathrm{a}\right)$. Low energy building level is reached, nZEB level is not reached.

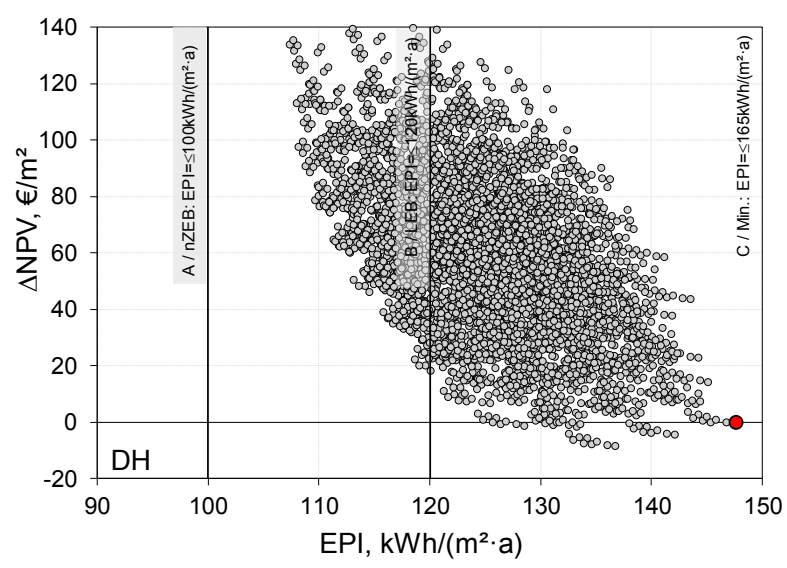

Fig. 7 Energy performance indicator (EPI) and change in the net present value $(\triangle \mathrm{NPV})$ for different combinations of structural solutions with the district heating.

In the case of a DH (Fig. 7), the cost-even range of energy performance indicator (EPI) without local production of renewable energy compared to the $\mathrm{BC}$ is between 125 and $147 \mathrm{kWh} /\left(\mathrm{m}^{2} \mathrm{a}\right)$. Low energy building level can be reached with extra investments compared to the $\mathrm{BC}, \mathrm{nZEB}$ level is not reached.

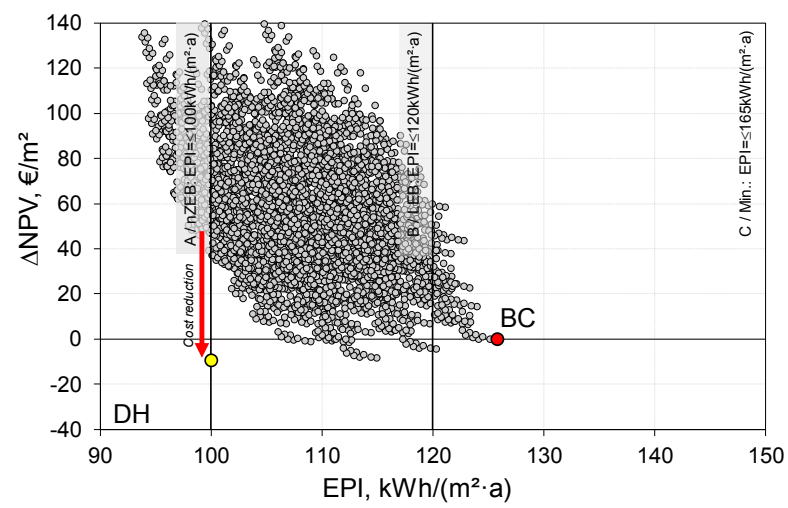

Fig. 8 Energy performance indicator (EPI) and change in the net present value $(\triangle \mathrm{NPV})$ for different combinations of structural solutions with the efficient district heating.

In the case of the effective DH (Fig. 8), the cost-even range of energy performance indicator (EPI) without local production of renewable energy compared to the $\mathrm{BC}$ is between 106 and $124 \mathrm{kWh} /\left(\mathrm{m}^{2} \mathrm{a}\right)$. Low energy building level can be reached with no extra investments compared to the $\mathrm{BC}$, to reach nZEB level extra investments is needed. 


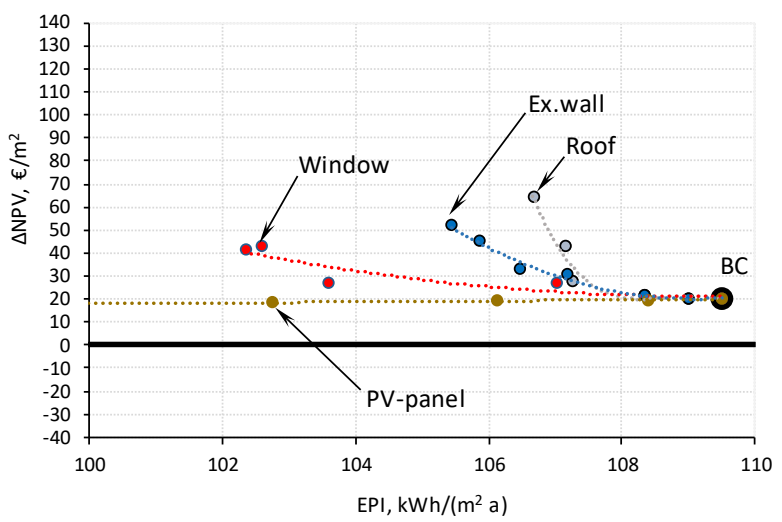

Fig. 9 Influence of the different improvement measures on EPI.

Influence of the different energy efficiency measures are presented on Fig. 9. The possible influence on the EPI depends on the combination of the solutions of the base case. The same applies also to the cost effectiveness. The presented graph shows the influence of insulations measures in case of the BC if the lowest EPI is reached with the lowest insulation measures in combination with the best building service and technical systems (ventilation with heat recovery system, very efficient heat source, LED lightning, low plug loads etc.). The result show that in all the cases installation of the PV-panels can be considered more cost effective than insulation measures.

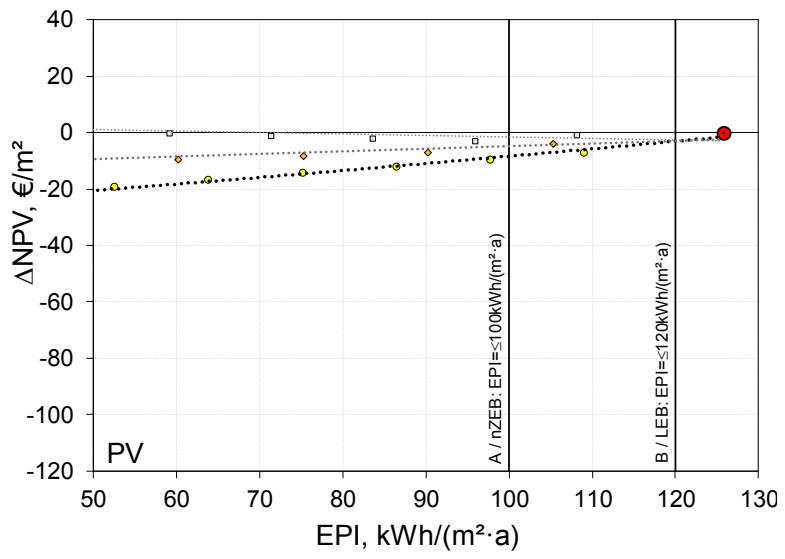

Fig. 10 Change of the net present value $(\triangle \mathrm{NPV})$ in case of different $\underline{\mathrm{PV} \text { solutions. }}$

Description of the lines on Fig. 10:

- lowest - PV panels on the horizontal surfaces (roof), $75 \%$ of the annual PV electricity production is considered to be used in the building;
- middle - PV panels on the horizontal surfaces (roof), in combination with batteries, $100 \%$ of the annual PV electricity production is considered to be used in the building;

- highest - PV panels on the vertical surfaces (wall), in combination with batteries, $100 \%$ of the annual PV electricity production is considered to be used in the building.

Fig. 10 reflects the trendlines of cost-effectiveness calculations of PV system in case of the selected building with different combinations of PV systems - PV on horizontal surface (roof), PV on horizontal surfaces with battery system, and PV on vertical surfaces. As installing of PV is cost effective measure, in some cases more PV is needed to install to equalizes the contractual measures.

Based on the definition of a nearly zero-energy building given in the Directive on Energy Performance of Buildings, local production of renewable energy is required to reach the nZEB level. Local generation of renewable energy is added below to the architecturally and technically appropriate combinations. Electricity generation with solar panels was considered as a solution for local production of renewable energy. Next figures show the results of cost-effectiveness calculations for selected building in different combinations of structural solutions, heat sources and local renewable energy production (with PV panels generating solar energy).

Table 4 gives the detailed energy performance related cost of the most cost-efficient solution compared with the reference solution (minimum requirements, BAU solutions)

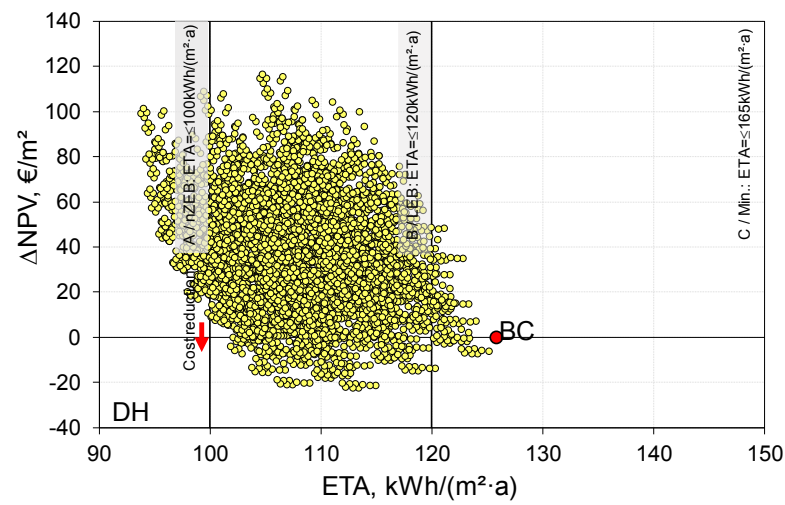

Fig. 11 Energy performance indicator (EPI) and change in the net present value $(\triangle \mathrm{NPV})$ for different combinations of structural solutions with the effective district heating and PVpanels. 
Table 4. Most efficient solutions compared to the reference building.

\begin{tabular}{|c|c|c|c|c|c|}
\hline & $\begin{array}{c}\text { Business as usual } \\
\text { solution }\end{array}$ & $\begin{array}{l}\text { The most cost optimal } \\
\text { building without PV }\end{array}$ & $\begin{array}{l}\text { The most cost optimal } \\
\text { building with PV }\end{array}$ & \multicolumn{2}{|c|}{$\begin{array}{c}\text { The least PV to reach } \\
\Delta \mathrm{NPV}=0\end{array}$} \\
\hline $\begin{array}{l}\text { Thermal transmittance } \\
\mathrm{W} /\left(\mathrm{m}^{2} \cdot \mathrm{K}\right) \text { and } \\
\text { airtightness of } \\
\text { building envelope } \\
\mathrm{m}^{3} /\left(\mathrm{m}^{2} \cdot \mathrm{h}\right)\end{array}$ & $\begin{array}{c}U_{\text {Ew }} 0.183 \\
U_{\mathrm{R}} 0.093 \\
U_{\mathrm{F}} 0.148 \\
U_{\mathrm{W}} 1.0 \\
q_{50} 1.5\end{array}$ & $\begin{array}{c}U_{\mathrm{EW}} 0.171 \\
U_{\mathrm{R}} 0.093 \\
U_{\mathrm{F}} 0.148 \\
U_{\mathrm{W}} 1.0 \\
q_{50} 1.5\end{array}$ & $\begin{array}{c}U_{\text {EW }} 0.171 \\
U_{\mathrm{R}} 0.093 \\
U_{\mathrm{F}} 0.112 \\
U_{\mathrm{W}} 1.0 \\
q_{50} 1.0\end{array}$ & $\begin{array}{c}U_{\mathrm{EW}} 0.153 \\
U_{\mathrm{R}} 0.07 \\
U_{\mathrm{F}} 0.10 \\
U_{\mathrm{W}} 0.7 \\
q_{50} 0.6\end{array}$ & $\begin{array}{c}U_{\text {EW }} 0.123 \\
U_{\mathrm{R}} 0.07 \\
U_{\mathrm{F}} 0.10 \\
U_{\mathrm{W}} 0.7 \\
q_{50} 1.0\end{array}$ \\
\hline $\begin{array}{l}\text { Specific fan power of } \\
\text { ventilation, } \\
\mathrm{kW} /\left(\mathrm{m}^{3} / \mathrm{s}\right)\end{array}$ & 1.75 & 1.5 & 1.5 & 1.5 & 1.5 \\
\hline Lighting power, W/m ${ }^{2}$ & 12 & 6 & 6 & 6 & 6 \\
\hline $\begin{array}{l}\text { Power of PV, } \\
\text { Wp/Neto } \mathrm{m}^{2}\end{array}$ & 0 & 0 & 32.8 & 10.5 & 17.4 \\
\hline ETA, $\mathrm{kWh} /\left(\mathrm{m}^{2} \cdot \mathrm{a}\right)$ & 126 & 115 & 100 & 100 & 100 \\
\hline$\Delta \mathrm{NPV}, € / \mathrm{m}^{2}$ & 0 & -8.8 & $-22,8$ & 0 & 0 \\
\hline
\end{tabular}

\section{Discussion}

The energy saved long-term as a result of more efficient insulation solutions lowers the annual energy costs. The costs are adjusted to current Euro values and are used to compare different combination packages. If the latter is equal to or smaller than the reference case, the insulation measure can be considered economically viable.

To compare the cost-effectiveness of different solutions, the investment cost and energy costs were used. The interest rate of the investment was chosen based on the Estonian National Bank's statistics and from current market loan interest rates. The uncertainty of the interest rate and the escalation of the energy price is high, but it ultimately has the same effect in the studied and reference building cases. Since the aim of the study was to compare the different scenarios, the energy and investment costs of energy saving measures were considered. The comparison was done relative to a reference building, so the relative values are more relevant than the absolute figures. The repair and maintenance costs were taken into account calculating the costs for the reference building.

The results for different combinations vary to a large degree. An economically optimal solution is assumed to be achieved if the $\triangle \mathrm{NPV}$ is the lowest. The results of the economic calculation show that higher energy savings gained by combining different insulation measures do not increase the cost-effectiveness. The reason for the drop is the ratio between the cost and the gained energy savings. As more efficient measures are more expensive investment costs and interest charges will be higher. The change of the heat source seems to have a significant impact on the EPI of the solution packages. Combining insulation measures with different heat sources results in significant difference of EPI. In the regulations it is stated that every new building must fulfill the low energy building (EPI class "B") requirement without local production. The EPI value to fulfill the EPI class " $\mathrm{B}$ " requirement in the cost-even range is reached in case of the GSHP and efficient DH. In case of the GSHP and efficient DH also the cost-optimal point is in the EPI class "B". Overall the minimum $\triangle \mathrm{NPV}$ values stay below the zero line in all the cases offering a range of opportunities to choose combinations to reach lover EPI compared to BC. Depending on the type of the building not all the electricity produced by PV can be considered in Estonia. In energy calculations $75 \%$ of the annual PV electricity production can be considered in case of the day care centers. Therefore, there is a need to increase the power of the installed PV panels or increasing the percentage of the electricity usage produced on site. First solution would be to install PV on free surfaces, second solution would be to add batteries for extending lifetime of assets and allowing more flexible usage.

The batteries are not common solution yet in the buildings. Although the PV panels seem to be first option to reach nZEB level the regulations command to deal first with the building envelope. In the regulations it is stated that every new building must fulfill the low energy building requirement without local production.

Priority is given to energy efficiency measures reducing the energy use, at least up to fulfill the low energy building requirement. Lower energy usage reduces also carbon emissions that is dependent on the heat source energy carrier. For the further studies the question about the carbon emissions is important. There may exist solutions that are not so cost effective but end in a lower carbon emission. To find best solutions for new nZEB both lifecycle cost and lifecycle emissions must be considered. An evaluation metric based on the correlation between the lifecycle cost and lifecycle emissions will define a matrix of assessment to find more efficient combinations of the different solutions.

\section{Conclusion}

Based on the calculations, for reduction of cost of new nZEB wooden buildings following actions are needed:

- Select efficient heat source (efficient district heating or ground source heat pump would be the first choices);

- Design compact building volume and windows according the need of natural lighting;

- Optimize the artificial lighting power according to the room's need and availability of natural lighting;

- Minimize the specific fan power of ventilation system;

- Design well insulated and airtight building envelope; 
- Optimize the onsite energy production from natural sources.

This research was supported by the Estonian Centre of Excellence in Zero Energy and Resource Efficient Smart Buildings and Districts, ZEBE (grant No. 2014-2020.4.01.150016) funded by the European Regional Development Fund, by the Estonian Research Council (grant No. PRG483), and by the European Commission through the H2020 project Finest Twins (grant No. 856602). This research utilises measurement data from H2020 project No 754177: "NERO - Cost reduction of new Nearly Zero-Energy Wooden buildings in the Northern Climatic Conditions".

\section{References}

1. Directive 2010/31/EU of the European Parliament and of the council of 19 May 2010 on the energy performance of buildings (recast). Official Journal of the European Union (2010).

2. Commission Delegated Regulation (EU) No 244/2012 of 16 January 2012 supplementing Directive 2010/31/EU of the European Parliament and of the Council on the energy performance of buildings by establishing a comparative methodology framework for calculating cost-optimal levels of minimum energy performance requirements for buildings and building elements. Official Journal of the European Union (2012).

3. E. Arumägi and T. Kalamees, Science and Technology for the Built Environment 22, (2016)

4. P. Heiselberg, H. Brohus, A. Hesselholt, H. Rasmussen, E. Seinre, and S. Thomas, Renewable Energy 34, 2030 (2009)

5. K. Kuusk, A. Kaiser, N. Lolli, J. Johansson, T. Hasu, A. Gunnarshaug Lien, E. Arumägi, K. Kalbe, J. Hallik, J. Kurnitski, and T. Kalamees, Journal of Sustainable Architecture and Civil Engineering 24, 7 (2019)

6. P. Sankelo, J. Jokisalo, J. Nyman, J. Vinha, and K. Sirén, International Journal of Sustainable Energy 1 (2018)

7. K. Alanne, J. Schade, I. Martinac, A. Saari, J. Jokisalo, and T. Kalamees, Advances in Building Energy Research 7, (2013)

8. R. Michelsson, J. Jokisalo, J. Kurnitski, A. Saari, K. Alanne, and T. Kalamees, Applied Energy 92, 76 (2012)

9. A. Marszal, J. Nørgaard, P. Heiselberg, and R. L. Jensen, in Proc. - 28th International PLEA Conference on Sustainable Architecture + Urban Design: Opportunities, Limits and Needs - Towards an Environmentally Responsible Architecture, PLEA 2012 (Lima; France, 2012), p. 6

8. Kurnitski, J., Saari, A., Kalamees, T., Vuolle, M., Niemelä, J., Tark, T. Estonian Journal of
Engineering 19, 183-202 (2013).

9. Estonian Regulation No 58: Methodology for calculating the energy performance of buildings. In Riigi Teataja (Ministry of Economic Affairs and Infrastructure, 2015).

10. EQUA. IDA Indoor Climate and Energy (IDAICE, version 4.7.1). (Equa Simulations AB, 2017). 